\title{
Empirical Analysis of Listed Agricultural Corporate Governance Structure and Corporate Performance
}

\author{
Danchen Zheng ${ }^{1, a}$ \\ ${ }^{1}$ Beijing Jiaotong University,Beijing, China
}

\begin{abstract}
Agriculture is the basic industry in China, and the development of agricultural listed companies is influenced by internal structure and corporate governance. An effective corporate governance structure can reduce costs to a certain extent, thereby increasing company value and overall strength. This paper selects the financial data of 2013-2018 A-share agricultural listed company in Shanghai and Shenzhen as a sample, puts forward the hypothesis through theoretical analysis, conducts Pearson correlation test on the sample data, and constructs multiple regression model to verify the three aspects of corporate governance structure. The relationship between corporate performance and research results shows that the relationship between equity concentration, equity balance, executive compensation and corporate performance of agricultural listed companies in China is in a " $U$ " shape, and the size of the board of directors is significantly positively correlated with corporate performance to some extent, while the correlation between other governance structural factors and firm performance is not significant.
\end{abstract}

\section{Introduction}

Agriculture is the pillar industry of China's economic development, and its development has received widespread attention. In recent years, with the increase of preferential policies, the agricultural industrialization has continued to develop, but the basic status of agriculture is fragile. Although government provides support for promoting agricultural innovation, agricultural companies still show low performance and uneven development levels, and there are low-quality accounting information disclosure and fraud violations.

The corporate governance structure is the main internal factor that affects the level of enterprise operation and development. It is of practical significance to select agriculture as a sample to study the relationship between corporate governance structure and corporate performance.

Domestic and foreign scholars have matured their research on corporate governance structure, but there are few specific studies on agriculture. Based on the data and related theoretical analysis of 38 agricultural listed companies from 2013 to 2018, this article uses multiple regression empirical methods to test the relationship between corporate governance structure and corporate performance, so as to find out the governance structure factors that hinder the development of corporate performance and to put forward reasonable suggestions for improving the performance of agricultural listed companies.

\section{Literature Review}

The study draws on Wu's definition of corporate governance structure which is an internal organizational mechanism that improves the principal-agent problem and achieves economic benefits by coordinating the relationship between shareholders, senior management and the board of directors [1].

In terms of corporate performance research, company stock prices and book values are two common indicators of measurement. The frequently used market indicator is Tobin $\mathrm{q}$, which uses the value of stocks to reflect market value; $\mathrm{Wu}$ and Huang used Tobin q to study how executive compensation affects company performance [2]. The rate of return on assets reflects the efficiency of the company's use of the invested capital. Li used this indicator to evaluate the profitability of selected sample companies [3].

In terms of research on the relationship between governance structure and company performance, domestic scholar Yao and Lin found that equity balance and concentration value have a significant positive impact on company performance [4]; Zhong conducted a study and found that the proportion of state-owned shares negatively affects companies [5]. Foreign scholars Jensen pointed out that an increase in the concentration of internal equity can effectively increase the value of a company. In the study of board governance [6]; Dong and Zhang found that the

a19120686@bjtu.edu.cn 
relationship between board size and company performance is not obvious [7]. Liang pointed out that independent directors have certain restrictions on the infringement of interests caused by the agency problem [8]. Foreign scholar Jensen believed that large-scale boards are not conducive for performance improving [9]. The analysis by Dye showed that the proportion of independent directors has a positive impact on the return on net assets [10]. In terms of executive incentives, Wang pointed out that executive incentives can significantly improve company performance [11] while foreign scholars Evans found no correlation between the two [12]. Karim believed that increasing the shareholding of senior management can increase the value of the company [13]. Due to industry differences, the factors and degrees of influence of different industry governance structures on corporate performance also differ. Feng pointed out that for the coal and petroleum industries, it has a significant positive effect on performance [14].

\section{Research Design}

Based on the industry classification of the CSRC, this article studies listed companies in agricultural industries such as agriculture, forestry, animal husbandry, vice and fishery, and selects 38 Shanghai and Shenzhen A-share agricultural listed companies from 2013 to 2018 as samples. The data comes from the annual financial reports disclosed by listed companies, the website of the CSRC and the CSMAR database. When selecting samples for this study, companies with abnormal financial performance and data were deleted to ensure the validity of the data.

\subsection{Variable Definition}

This study uses return on equity (ROE) and Tobin's Q as the dependent variables to measure corporate performance. Among them, ROE is the dependent variable of the regression analysis model. Tobin's Q is used as the explanatory variable of the robustness test. verification. This paper selects seven explanatory variables: equity concentration, equity balance, board size, the proportion of independent directors, the number of board meetings, the share of senior management holdings, and executive compensation. At the same time, the asset-liability ratio and the company's growth potential are used as control variables to reduce the impact of other factors in the model. The growth of the company reflects the improvement of the company's development capabilities and the improvement of the company's comprehensive competitiveness. This article uses the asset growth rate to reflect the company's growth.

The variables are defined in Table 1.

Table1. Variable design table

\begin{tabular}{|c|c|c|c|}
\hline $\begin{array}{c}\text { Variable } \\
\text { properties }\end{array}$ & Classification & Variable definitions & Symbol \\
\hline & Performance & Tobin Q & $\mathrm{TQ}$ \\
\hline
\end{tabular}

\begin{tabular}{|c|c|c|c|}
\hline $\begin{array}{l}\text { Dependent } \\
\text { variable }\end{array}$ & & Return on Equity & ROE \\
\hline \multirow{7}{*}{$\begin{array}{l}\text { Independent } \\
\text { variable }\end{array}$} & \multirow{2}{*}{$\begin{array}{l}\text { Ownership } \\
\text { structure }\end{array}$} & Equity concentration & CR \\
\hline & & Equity Balance & Z \\
\hline & \multirow{3}{*}{$\begin{array}{l}\text { Board } \\
\text { Governance }\end{array}$} & Board Size & BDS \\
\hline & & $\begin{array}{c}\text { Proportion of independent } \\
\text { directors }\end{array}$ & IDBD \\
\hline & & Board meetings & BDM \\
\hline & \multirow{2}{*}{$\begin{array}{l}\text { Executive } \\
\text { motivation }\end{array}$} & $\begin{array}{c}\text { Management shareholding } \\
\text { ratio } \\
\end{array}$ & CRCEO \\
\hline & & Executive compensation & REM \\
\hline \multirow{2}{*}{$\begin{array}{l}\text { Control } \\
\text { variable }\end{array}$} & $\begin{array}{l}\text { Capital } \\
\text { Structure }\end{array}$ & Assets and liabilities & DAR \\
\hline & $\begin{array}{l}\text { Growth } \\
\text { Ability }\end{array}$ & Company growth & GRO \\
\hline
\end{tabular}

\subsection{Model Building}

Considering the non-linear relationship between governance structure factors and performance, linear and non-linear equation models are established to investigate the influence of each factor. Model 1 establishes a linear relationship, and Model two considers the possible existence of the square term, and adds the square term to the regression equation. Therefore, we build the following model.

$$
\begin{gathered}
R O E=\beta_{0}+\beta_{1} \times D A R+\beta_{2} \times G R O+\beta_{3} X_{i}+\varepsilon \\
R O E=\beta_{0}+\beta_{1} \times D A R+\beta_{2} \times G R O+\beta_{3} X_{i}+\beta_{4} X_{i}^{2}+
\end{gathered}
$$

The model using TQ as the dependent variable for robustness testing is as follows:

$$
\begin{aligned}
& T Q=\beta_{0}+\beta_{1} \times D A R+\beta_{2} \times G R O+\beta_{3} X_{i}+\varepsilon(3) \\
& T Q=\beta_{0}+\beta_{1} \times D A R+\beta_{2} \times G R O+\beta_{3} X_{i}+\beta_{4} X_{i}^{2}+
\end{aligned}
$$

$\beta_{0}$ is the intercept term, $\beta_{1}, \beta_{2} 、 \beta_{3}, \beta_{4}$ are the regression coefficients of the independent and control variables, $\varepsilon$ is the residual term。

\section{Empirical results}

\subsection{Descriptive Statistics}

\subsubsection{Descriptive analysis of explanatory variables}

Table2. Descriptive statistics of governance structure factors from 2016 to 2018

\begin{tabular}{|c|l|c|c|c|c|}
\hline Year & Variables & Min & Max & Mean & Std. Dev. \\
\hline \multirow{8}{*}{2016} & CR & 4.150 & 70.320 & 33.734 & 250.795 \\
\cline { 2 - 6 } & Z & 0.045 & 5.253 & 0.931 & 1.051 \\
\cline { 2 - 6 } & BDS & 5.000 & 15.000 & 8.340 & 4.447 \\
\cline { 2 - 6 } & IDBD & 0.330 & 0.600 & 0.385 & 0.004 \\
\cline { 2 - 6 } & BDM & 4.000 & 16.000 & 9.130 & 10.550 \\
\cline { 2 - 6 } & CRCEO & 0.000 & 0.546 & 0.068 & 0.022 \\
\cline { 2 - 6 } & REM & 12.840 & 300.000 & 52.890 & 0.989 \\
\hline
\end{tabular}




\begin{tabular}{|l|l|c|c|c|c|}
\hline \multirow{5}{*}{2017} & CR & 4.150 & 70.320 & 33.030 & 250.886 \\
\cline { 2 - 6 } & Z & 0.044 & 5.258 & 1.009 & 1.374 \\
\cline { 2 - 6 } & BDS & 5.000 & 16.000 & 8.290 & 4.860 \\
\cline { 2 - 6 } & IDBD & 0.310 & 0.600 & 0.385 & 0.004 \\
\cline { 2 - 6 } & BDM & 4.000 & 18.000 & 9.920 & 13.318 \\
\cline { 2 - 6 } & CRCEO & 0.000 & 0.437 & 0.058 & 0.015 \\
\cline { 2 - 6 } & REM & 12.64 & 383.220 & 58.830 & 1.475 \\
\hline \multirow{5}{*}{2018} & CR & 4.080 & 64.140 & 35.325 & 212.335 \\
\cline { 2 - 6 } & Z & 0.056 & 5.257 & 0.891 & 1.174 \\
\cline { 2 - 6 } & BDS & 5.000 & 12.000 & 8.080 & 3.274 \\
\cline { 2 - 6 } & IDBD & 0.330 & 0.600 & 0.384 & 0.004 \\
\cline { 2 - 6 } & BDM & 4.000 & 18.000 & 10.000 & 16.720 \\
\cline { 2 - 6 } & CRCEO & 0.000 & 0.428 & 0.049 & 0.010 \\
\cline { 2 - 6 } & REM & 13.670 & 383.220 & 78.770 & 1.357 \\
\hline
\end{tabular}

According to the descriptive analysis results in Table 2, in terms of shareholding structure, the equity concentration of agricultural listed companies and the balance of equity are not balanced. The minimum balance of equity in 2015 is 0.047 , and the highest is 5.188. The maximum size of the board of directors is more than 10 , and the minimum value is 4 . The size of the board is stable. The proportion of independent directors also remained stable, fluctuating around 0.380 . The number of management meetings fluctuated within the range.

The maximum share held by management is 0.4 , and the industry average has remained basically unchanged. The maximum and minimum values of executive compensation have increased significantly, and the average value has increased from 587300 to 787700 after 2017, showing a rapid growth.

\subsubsection{Descriptive analysis of explained variables}

Table3. Descriptive statistics of enterprise performance indicators from 2013 to 2018

\begin{tabular}{|c|c|c|c|c|}
\hline ROE & Min & Max & Mean & Std. Dev. \\
\hline 2013 & -35.47 & 27.04 & 3.04 & 127.63 \\
\hline 2014 & -9.17 & 20.84 & 4.01 & 44.97 \\
\hline 2015 & -78.41 & 34.95 & 0.59 & 329.63 \\
\hline 2016 & -55.68 & 50.74 & 6.65 & 324.58 \\
\hline 2017 & -62.45 & 28.12 & 0.81 & 288.82 \\
\hline 2018 & -37.54 & 40.92 & 5.76 & 210.77 \\
\hline
\end{tabular}

According to the analysis results in Table 3, from 2014 to 2015 , the average return on net assets decreased from 4.0 to 0.58 ; from 2016 to 2017 , the return on net assets decreased from 6.64 to 0.8 , and then increased rapidly to 5.76. The operating conditions of agricultural companies are affected by various factors, which fluctuate greatly. In recent years, the variance of the ROE index reflecting corporate performance has decreased, but excessive variance also indicates the industry's greater volatility risk.

\subsection{Correlation Test}

In correlation test, there is a significant correlation between the return on net assets, the balance of equity, and the shareholding ratio of management; the relationship between the squared value of equity, the size of the board of directors, management compensation, and corporate performance is not significant. Because the correlation coefficients between independent variables are less than 0.5 , there is almost no multicollinearity problem. Therefore, the respective variables are added to the regression model for analysis.

\subsection{Multiple Regression Analysiss}

A multiple regression model with all variables is constructed as follows:

The regression results shown in the following table are obtained.

Table4. Regression coefficients

\begin{tabular}{|c|c|c|c|c|c|c|}
\hline & & \multicolumn{2}{|c|}{$\begin{array}{l}\text { Unstandardized } \\
\text { coefficient }\end{array}$} & \multirow{2}{*}{$\begin{array}{c}\begin{array}{c}\text { Standard } \\
\text { regression } \\
\text { coefficient }\end{array} \\
\text { Beta }\end{array}$} & \multirow[b]{2}{*}{$\mathbf{t}$} & \multirow[b]{2}{*}{ Sig } \\
\hline \multicolumn{2}{|c|}{ Model } & B & SE & & & \\
\hline \multirow[t]{10}{*}{1} & (con) & -5.615 & 10.654 & & -0.527 & 0.599 \\
\hline & CR2 & 0.002 & 0.001 & 0.130 & 2.006 & 0.031 \\
\hline & $\mathrm{Z2}$ & 0.500 & 0.255 & 0.142 & 1.963 & 0.049 \\
\hline & BDS & 1.033 & 0.594 & 0.136 & 1.738 & 0.053 \\
\hline & IDBD & 18.680 & 18.222 & 0.075 & 1.025 & 0.307 \\
\hline & BDM & -0.084 & 0.280 & -0.019 & -0.301 & 0.764 \\
\hline & CRCEO & 4.669 & 7.766 & 0.043 & 0.601 & 0.548 \\
\hline & REM & $4.495 \mathrm{E}-7$ & 0.000 & 0.034 & 0.524 & 0.601 \\
\hline & DAR & -30.547 & 5.170 & -0.366 & -5.909 & 0.000 \\
\hline & GRO & 24.379 & 4.668 & 0.355 & 5.223 & 0.000 \\
\hline
\end{tabular}

From the regression coefficients table, the degrees of equity concentration and equity balance are significant at a confidence level of 0.05 , and the coefficients are 0.130 and 0.142 respectively. The linear relationship between other variables and corporate performance is not significant, so this study further conducts separate regression analysis on specific variables to establish linear and non-linear regression equations respectively.

\subsubsection{Ownership structure and performance analysis}

The regression analysis of equity structure and company performance is following.

Table5. Regression coefficients of equity concentration and performance

\begin{tabular}{|c|c|c|c|c|c|c|}
\hline \multicolumn{2}{|c|}{ Model } & \multicolumn{2}{|c|}{$\begin{array}{c}\text { Unstandardized } \\
\text { coefficient }\end{array}$} & $\begin{array}{c}\text { Standard } \\
\text { regression } \\
\text { coefficient }\end{array}$ & \multirow{2}{*}{} & \multirow{2}{*}{ Sig } \\
\cline { 3 - 7 } & B & SE & Beta & t & S \\
\hline \multirow{3}{*}{1} & (con) & 18.830 & 4.296 & & 4.383 & 0.000 \\
\cline { 2 - 7 } & CR & -0.493 & 0.221 & -0.521 & -2.232 & 0.027 \\
\cline { 2 - 7 } & CR2 & 0.007 & 0.003 & 0.589 & 2.523 & 0.012 \\
\cline { 2 - 7 } & DAR & -29.804 & 4.959 & -0.357 & -6.010 & 0.000 \\
\cline { 2 - 6 } & GRO & 27.622 & 4.081 & 0.402 & 6.768 & 0.000 \\
\hline
\end{tabular}


It is concluded that the squared shareholding of the largest shareholder has a positive correlation with corporate performance, and the shareholding and performance of the largest shareholder have an inverted U-shaped relationship. To a certain extent, the more concentrated the equity, the performance will increase; but the excessive concentration of equity leads to the protection of other shareholders' rights and interests, affecting the management efficiency and performance of the enterprise.

Table6. Regression coefficients of ownership balance and performance

\begin{tabular}{|c|c|c|c|c|c|c|}
\hline \multirow{2}{*}{ Model } & \multicolumn{2}{|c|}{$\begin{array}{c}\text { Unstandardized } \\
\text { coefficient }\end{array}$} & $\begin{array}{c}\text { Standard } \\
\text { regression } \\
\text { coefficient }\end{array}$ & & \multirow{2}{*}{ S } \\
\cline { 2 - 5 } & B & SE & Beta & Sig \\
\hline \multirow{3}{*}{1} & (con) & 11.510 & 2.333 & & 4.933 & 0.000 \\
\cline { 2 - 7 } & Z & -0.414 & 0.466 & -0.057 & -0.887 & 0.376 \\
\cline { 2 - 7 } & Z2 & 0.587 & 0.227 & 0.167 & 2.586 & 0.010 \\
\cline { 2 - 7 } & DAR & -28.841 & 4.980 & -0.346 & -5.791 & 0.000 \\
\cline { 2 - 7 } & GRO & 25.835 & 4.086 & 0.376 & 6.322 & 0.000 \\
\hline
\end{tabular}

Non-linear regression analysis showed that the square of the value of agricultural listed companies with equity restriction of the significant positive correlation. In order to enhance corporate performance guarantee, equity restriction of the need to control within reasonable limits. Oversight and management role is too small checks and balances of equity means that minority shareholders are weakened.

\subsubsection{Board structure and firm performance analysis}

Table7. Regression coefficients of board size and performance

\begin{tabular}{|c|c|c|c|c|c|c|}
\hline \multirow{2}{*}{ Model } & \multicolumn{2}{|c|}{$\begin{array}{c}\text { Unstandardized } \\
\text { coefficient }\end{array}$} & $\begin{array}{c}\text { Standard } \\
\text { regression } \\
\text { coefficient }\end{array}$ & & \multirow{2}{*}{ Sig } \\
\cline { 2 - 5 } \multicolumn{2}{|c|}{ B } & SE & Beta & t & Sig \\
\hline \multirow{2}{*}{1} & (con) & 3.313 & 4.025 & & 0.823 & 0.411 \\
\cline { 2 - 7 } & BDS & 1.220 & 0.461 & 0.160 & 2.649 & 0.009 \\
\cline { 2 - 7 } & DAR & -32.169 & 5.029 & -0.386 & -6.397 & 0.000 \\
\cline { 2 - 7 } & GRO & 25.872 & 4.068 & 0.377 & 6.360 & 0.000 \\
\hline
\end{tabular}

As shown in the table, there is a significant positive correlation between the size of the board of directors and the return on net assets. The board of directors of China's agricultural listed companies is not perfect. In the current stage, a moderately sized board can play an important role in corporate decision-making. But too many or too few board members limit the company's ability to increase its value.

Table8. Regression coefficients of proportion of independent directors and performance

\begin{tabular}{|c|c|c|c|c|c|c|}
\hline \multirow{2}{*}{ Model } & \multicolumn{2}{|c|}{$\begin{array}{c}\text { Unstandardized } \\
\text { coefficient }\end{array}$} & $\begin{array}{c}\text { Standard } \\
\text { regression } \\
\text { coefficient }\end{array}$ & & \multirow{2}{*}{ Sig } \\
\cline { 2 - 7 } & B & SE & Beta & t & Sig \\
\hline \multirow{2}{*}{1} & (con) & 25.473 & 29.427 & & 0.866 & 0.388 \\
\cline { 2 - 7 } & IDBD & -58.911 & 136.793 & -0.237 & -0.431 & 0.667 \\
\cline { 2 - 7 } & DAR & -29.968 & 5.145 & -0.359 & -5.824 & 0.000 \\
\cline { 2 - 7 } & GRO & 26.593 & 4.139 & 0.387 & 6.426 & 0.000 \\
\hline
\end{tabular}

\begin{tabular}{|l|l|l|l|l|l|l|}
\hline & IDBD2 & 63.157 & 157.130 & 0.221 & 0.402 & 0.688 \\
\hline
\end{tabular}

The regression results show that the proportion of independent directors does not have a significant positive impact on performance. The ratio of independent directors of listed agricultural companies in China is controlled within a relatively stable range, and the average ratio of independent directors in the past six years is about 0.38 , so this indicator has no obvious impact on agricultural enterprises.

Table9. Regression coefficients of proportion of board meetings and performance

\begin{tabular}{|c|c|c|c|c|c|c|}
\hline \multirow{2}{*}{ Model } & \multicolumn{2}{|c|}{$\begin{array}{c}\text { Unstandardized } \\
\text { coefficient }\end{array}$} & $\begin{array}{c}\text { Standard } \\
\text { regression } \\
\text { coefficient }\end{array}$ & & \\
\cline { 2 - 5 } \multicolumn{2}{|c|}{ B } & SE & Beta & t & Sig \\
\hline \multirow{2}{*}{1} & (con) & 19.529 & 6.520 & & 2.995 & 0.003 \\
\cline { 2 - 7 } & BDM & -1.754 & 1.326 & -0.404 & -1.323 & 0.187 \\
\cline { 2 - 7 } & DAR & -28.545 & 5.064 & -0.342 & -5.637 & 0.000 \\
\cline { 2 - 7 } & GRO & 26.470 & 4.229 & 0.385 & 6.258 & 0.000 \\
\cline { 2 - 7 } & BDM2 & 0.088 & 0.062 & 0.430 & 1.413 & 0.159 \\
\hline
\end{tabular}

Regression analysis showed that the correlation between the number of meetings and company performance was not significant. The reason may be that the annual board meeting frequency of China's agricultural listed companies changes little.

\subsubsection{Management structure and corporate performance analysis}

Table10. Regression coefficients of management's shareholding ratio and performance

\begin{tabular}{|c|c|c|c|c|c|c|}
\hline \multirow{2}{*}{\multicolumn{2}{|c|}{ Model }} & \multicolumn{2}{|c|}{$\begin{array}{c}\text { Unstandardized } \\
\text { coefficient }\end{array}$} & \multirow{2}{*}{$\begin{array}{c}\begin{array}{c}\text { Standard } \\
\text { regression } \\
\text { coefficient }\end{array} \\
\text { Beta } \\
\end{array}$} & \multirow[b]{2}{*}{$\mathbf{t}$} & \multirow[b]{2}{*}{ Sig } \\
\hline & & B & SE & & & \\
\hline \multirow[t]{4}{*}{1} & (con) & 12.501 & 2.313 & & 5.405 & 0.000 \\
\hline & CRCEO & -11.480 & 30.467 & 0.105 & 0.377 & 0.207 \\
\hline & DAR & -30.173 & 5.042 & -0.362 & -5.984 & 0.000 \\
\hline & GRO & 24.920 & 4.686 & 0.363 & 5.318 & 0.000 \\
\hline
\end{tabular}

The correlation coefficient between the management's shareholding ratio and the company's performance is 0.105 , which fails the significance test, indicating that the positive impact of the management's shareholding ratio on performance is not obvious. Due to the imperfect equity incentive system and the lack of management of the management of listed agricultural companies in China, the shareholding of senior management has no significant impact on performance.

Table11. Regression coefficients of executive compensation and performance

\begin{tabular}{|c|c|c|c|c|c|c|}
\hline \multirow{2}{*}{\multicolumn{2}{|c|}{ Model }} & \multicolumn{2}{|c|}{$\begin{array}{c}\text { Unstandardized } \\
\text { coefficient }\end{array}$} & \multirow{2}{*}{$\begin{array}{c}\begin{array}{c}\text { Standard } \\
\text { regression } \\
\text { coefficient }\end{array} \\
\text { Beta } \\
\end{array}$} & \multirow[b]{2}{*}{$\mathbf{t}$} & \multirow[b]{2}{*}{ Sig } \\
\hline & & B & SE & & & \\
\hline \multirow[t]{2}{*}{1} & (con) & 9.968 & 2.404 & & 4.147 & 0.000 \\
\hline & REM & $5.026 \mathrm{E}-6$ & 0.000 & 0.376 & 2.503 & 0.013 \\
\hline
\end{tabular}




\begin{tabular}{cccccc}
\hline DAR & -29.031 & 4.948 & -0.348 & -5.867 & 0.000 \\
GRO & 24.929 & 4.178 & 0.363 & 5.966 & 0.000 \\
REM2 & $-3.374 \mathrm{E}-13$ & 0.000 & -0.329 & -2.213 & 0.028 \\
\hline
\end{tabular}

According to the regression results, there is a quadratic correlation between executive compensation and company performance, with a quadratic coefficient of -0.329 and a $P$ value of 0.028 , which passed the test significantly. In a certain range, executive compensation has a positive effect on corporate performance. Too high or too low executive compensation is not conducive to the improvement of corporate performance.

\subsection{Robustness Test}

The robustness test uses the Tobin $\mathrm{Q}$ value to measure financial performance, using the second largest shareholder's shares instead of the second to ten largest shareholders' shares, and using the maximum executive compensation to reflect management incentives. Correlation analysis and regression analysis were performed again to obtain consistent results, so the robustness test of the empirical model of this study was passed.

\section{Research Conclusions and Policy Suggestions}

\subsection{Research Conclusions}

This article selected 38 listed companies in agricultural listed companies from 2013 to 2018 as a sample to conduct empirical research and theoretical analysis of the company's internal governance structure and corporate performance. First, the concentration of equity and the balance of equity within a reasonable range have a positive impact on the company. Shareholders have paid more attention to the development of the company in pursuit of benefits. Second, the size of the board of directors is positively promoting corporate performance to a certain extent, and the number of board meetings and the proportion of independent directors are not obvious. The board of larger agricultural listed companies can promote decision-making. Third, a reasonable set of executive compensation can improve the company's performance, but the executive shareholding ratio has no significant impact on performance.

\subsection{Policy Suggestions}

\subsubsection{Supporting agricultural development}

Relevant departments should introduce preferential tax policies and other subsidy measures to protect the interests of enterprises and farmers. The government should provide technical training guidance for farmers, implement innovative incentive mechanisms, and help enterprises improve their overall strength.

\subsubsection{Improving corporate equity structure}

China's agricultural listed companies should coordinate the relationship between the concentration of equity and the balance of equity. They should establish a balanced equity structure of reasonable size according to the actual situation of the company. For agricultural enterprises, state-owned enterprises account for the majority. Specifically, improving equity structure can introduce strategic investment, implement employee shareholding, and restructure and reorganize. The realization of diversified equity in terms of employee incentives can have a good effect.

\subsubsection{Optimizing board governance structure}

The structure of the board of directors needs to be improved from the number of board members and the number of independent directors. When an enterprise selects members of the board of directors, it is necessary to evaluate the comprehensive ability of employees to ensure the quality of the board of directors. Enterprises should improve the management system for independent directors, give play to the role of corporate development and performance improvement, and focus on improving meeting quality and decision-making efficiency.

\subsubsection{Improving the compensation and equity incentive system}

Through the way of compensation and reward, employees value the operating efficiency of the enterprise. Some agricultural family businesses have disadvantages, unstable earnings, and increased labor costs. Allocating equity can retain core talents, reduce cash and labor costs, cash outlays, and improve profitability. At the same time, the selection of equity incentive strategies needs to be based on the company's specific circumstances, including excess profit incentives, on-the-job dividends, and virtual stock incentives. Companies should consider the employee's level of knowledge and responsibilities when examining the employee's job value and historical contribution.

\section{References}

1. J. L. Wu, Modern Company and Enterprise Reform. Tianjin: Tianjin People's Publishing House, 2005.

2. H. B. Wu and X. B. Huang, " Executive compensation and firm performance: evidence from listed manufacturing companies in Shenzhen stock exchange," Modern Business Trade Industry, vol. 39, no. 24, pp. 93-95, 2018.

3. Z. J. Li, C. T. Chen, and L. X. Ru, " An analysis of bank ownership and corporate profitability from the perspective of corporate governance — based on empirical evidence of A-share listed companies in Shanghai and Shenzhen," Finance and Accounting for 
International Commerce, vol. 01, pp. 75-80, 2015.

4. B. B. Yao and A. H. Lin, "Ownership structure, agency cost and firm performance," Communication of Finance and Accounting, vol. 27, pp. 56-58, 2018.

5. Y. Y. Zhong, " Research on the relationship between the proportion of state-owned shares and enterprise performance under the background of mixed ownership reform," University of Henan, 2016.

6. M. Jensen, " Agency costs of free cash flow, corporate finance, and takeover," American Economic Review, vol. 76, pp. 323-329, 1986.

7. B. Dong and Z. Zhang, " Ownership structure, board characteristics and corporate performance: an endogenous perspective," Journal of Dalian University of Technology (Social Science Edition), vol. 04, 2015.

8. X. S. Liang, " Research on the relationship between ultimate control of pyramid structure, board characteristics and company performance," Management and Administration, vol. 03, pp. 111-113, 2017.

9. M. Jensen, " The modem industrial revolution, exit and the failure of internal control systems," Journal of Finance, vol. 48, no. 05, pp. 831-880, 1993.

10. R. A. Dye, " An evaluation of essays on disclosure and the disclosure literature in accounting," Journal of Accounting and Economics, vol. 32, pp. 181-235, 2014.

11. Y. H. Wang, " Executive incentive, internationalization degree and firm performance," Communication of Finance and Accounting, vol. 24, pp. 54-57, 2018.

12. J. Evans and R. Evans, " An examination of economic value added and executive compensation," Journal of Political Economy, vol. 95, pp. 1155-1177, 2011.

13. R. Karim, S. Zeina and Z. Luigi, " The cost of diversity: the diversification discount and inefficient investment," Journal of Finance, vol. 60, pp. 35-80, 2013.

14. T. Z. Feng, Y. Zhang and G. Zhang, " Research on the influence of listed company's governance structure on performance based on unbalanced panel data of coal industry," China Coal, vol. 43, no. 06, pp. 11-16, 2017. 